\title{
UMBATRA
}

Indonesian Journal of Anthropology

Volume 4 (2) Desember 2019 || eISSN 2528-1569

DOI : 10.24198/umbara.v4i2.25368

pISSN 2528-2115 || http://jurnal.unpad.ac.id/umbara

\section{Peran Kewirausahaan Sosial dalam Pemberdayaan Masyarakat: Tiga Cerita dari Kutai Timur}

\author{
Denny Riezki Pratama \\ PT Kaltim Prima Coal \\ denny.riezkipratama@gmail.com
}

\begin{abstract}
Corporate Social Responsibility (CSR) and community development initiatives grow rapidly in recent years. It's an act of a business ethics by taking part in efforts to achieve sustainable development goals (SDGs). It does not have economic value per se, but also social, cultural and political by involving local agent and existing cultural institutions which in turn catalyse the emergence and the redefinition of local social-political movement. This study discusses the emergence of local agent and their significant roles as social entrepreneur in the community development program initiated by Kaltim Prima Coal (KPC) in East Kalimantan province. This study employs qualitative method. Primary data were gathered from interviews and participant-observations, while secondary data were gathered from company reports and company internal presentation materials. The main qualitative data are short stories of three social entrepreneurs live in the mining areas who network with CSR and community development program of PT. Kaltim Prima Coal. This study suggests that social entrepreneurs are the key success of community development program, because they have the capability to foster members of their community to be innovative and creative, as well seize their opportunity for empowerment and to increase community members participation in development. The social entrepreneur have a strong bonding with local culture even though they are not native of their locality. In some cases, social entrepreneurs initiate the local socio-political movement and they do not merely play their role as social broker.
\end{abstract}

Keywords: CSR, community development, social entrepreneurship, mining, ethnography

\begin{abstract}
Abstrak
Tanggung Jawab Sosial Perusahaan (CSR) dan inisiatif pemberdayaan masyarakat tumbuh pesat dewasa ini, sebagai perwujudan etika bisnis melalui partisipasi perusahaan dalam pencapaian pembangunan berkelanjutan (SDGs). CSR tidak hanya bernilai ekonomis, tetapi juga sosial, budaya dan politik. Pelibatan agen dan lembaga budaya lokal dalam program CSR dan pemberdayaan masyarakat, seringkali mendorong munculnya gerakan sosial-politik lokal. Studi ini membahas proses kemunculan dan peran agen lokal dalam kewirausahaan sosial dalam konteks program CSR dan pemberdayaan masyarakat
\end{abstract}


yang diselenggarakan oleh PT Kaltim Prima Coal (KPC) di Provinsi Kalimantan Timur. Studi ini menggunakan metode kualitatif. Data primer dikumpulkan melalui wawancara dan pengamatan terlibat. Data sekunder berasal dari laporan dan materi presentasi internal perusahaan. Data utama berupa cerita mendalam mengenai tiga pelaku wirausaha sosial yang didampingi program CSR dan pemberdayaan masyarakat PT. Kaltim Prima Coal. Hasil penelitian menunjukkan bahwa kunci program pemberdayaan masyarakat adalah para pelaku wirausaha sosial. Sebab, mereka berperan mendorong masyarakat untuk lebih inovatif dan kreatif memanfaatkan peluang pemberdayaan dan mendorong peningkatan partisipasi masyarakat dalam pembangunan. Para pelaku wirausaha sosial memiliki ikatan budaya yang kuat pada lokalitasnya meski mereka bukan warga asli setempat. Bahkan, mereka dapat mendorong munculnya gerakan sosial-politik lokal dan bukan sekedar menjadi makelar sosial.

Kata kunci : CSR, pengembangan masyarakat, kewirausahaan sosial, pertambangan, etnografi

\section{Pendahuluan}

Tanggung jawab sosial perusahaan atau Corporate Social Responsibility (CSR) adalah sebuah aksi filantropi dan perwujudan etika bisnis perusahaan. Pada mulanya CSR bertujuan mewujudkan tanggung jawab sektor usaha dalam rangka memaksimalkan keuntungan bagi pemangku saham dan pemangku kepentingan. Kini, CSR berkembang menjadi wadah bagi perusahaan untuk turut berpartisipasi dalam pembangunan berkelanjutan ${ }^{1}$. Moon, Anastiadis dan Vigano mendefinisikan CSR sebagai kegiatan "beyond-compliance contribution of companies to social, environmental, and ethical concerns" (Moon, Anastiadis, dan Vigano dalam Camilleri, 2017). Artinya, kegiatan tanggung jawab sektor usaha tidak hanya untuk memaksimalkan keuntungan pemangku saham dan pemangku kepentingan semata tetapi juga sebagai jalan bagi dunia usaha untuk terlibat dalam menanggulangi masalah sosial. Hal ini dilakukan, salah satunya, melalui kegiatan pemberdayaan dan pengembangan masyarakat. Oleh karena itu, konsep CSR di Indonesia sering dipertukarkan dengan konsep pemberdayaan masyarakat. Kegiatan pengembangan/pemberdayaan masyarakat merupakan salah satu dari tujuh subjek inti tanggung jawab sosial (ISO 26000, 2010). Tren CSR di Indonesia menunjukkan perkembangan pesat dalam dua dekade terakhir, terlihat dari peningkatan jumlah perusahaan yang mengikuti ajang penghargaan. ${ }^{2}$ NCSR mencatat, pada 2005 hanya tujuh perusahaan yang mengikuti Indonesia Sustainability Reporting Award (ISRA) ${ }^{3}$. Pada 2019, sebanyak 56 perusahaan mengikuti Asia Sustainability Reporting Rating (ASR Rating). Artinya, terjadi kenaikan tingkat partisipasi perusahaan sebesar

\footnotetext{
${ }^{1}$ Sustainable Development Goals (SDGs) atau pembangunan berkelanjutan dicanangkan oleh PBB pada 2015 menggantikan Millenuim Development Goals yang pernah diluncurkan pada 2000. SDGs telah diratifikasi oleh 189 negara, termasuk Indonesia. Tiga pilar utama SDGs adalah lingkungan, sosial dan ekonomi; sedangkan tujuan spesifiknya meliputi tujuh belas hal, di antaranya pengentasan kemiskinan dan kelaparan, pekerjaan layak dan pertumbuhan ekonomi, serta kota dan komunitas berkelanjutan (https://www.un.org/ sustainabledevelopment/). Kebijakan dan institusi dunia harus saling terkait dalam mendukung upaya pencapaian pembangunan berkelanjutan (Brundtland, 1987).

2 NCSR adalah organisasi independen pertama yang mengembangkan pelaporan keberlanjutan di Indonesia dan organisasi pertama yang memperkenalkan istilah "laporan keberlanjutan" di Indonesia. NCSR fokus pada pengenalan dan pelatihan sistem laporan berkelanjutan bagi organisasi dan profesional agar "memiliki kemampuan untuk mengelola departemen CSR dan membuat laporan keberlanjutan.” NCSR salah satu lembaga penting dalam diseminasi wacana CSR sekaligus penyelenggara ajang penghargaan CSR Indonesia. Lebih lanjut lihat (National Center for Sustainability Reporting, n.d.-b) https://www.ncsr-id.org/id/about-ncsr/the-board/about-ncsr/.

3 ISRA adalah ajang penghargaan tahunan yang diselenggarakan oleh NCSR bagi perusahaan yang melaporkan secara terbuka kinerja CSR-nya.
} 
tujuh kali lipat dalam kurun waktu 14 tahun terakhir. Pengarusutamaan wacana CSR di Indonesia juga tampak dari makin banyaknya undang-undang dan peraturan formal dalam dunia usaha, khususnya pertambangan, yang memusatkan perhatian pada tanggung jawab sosial, lingkungan, pengembangan, dan pemberdayaan masyarakat.

PT. Kaltim Prima Coal (selanjutnya disingkat PT. KPC) adalah salah satu perusahaan tambang batu bara di Indonesia yang melaksanakan aneka kegiatan pemberdayaan masyarakat melalui CSR-nya. Perusahaan ini merupakan perusahaan tambang batu bara terbesar di dunia. Jumlah Penerimaan Negara Bukan Pajak (PNBP) yang disetor oleh perusahaan ini pada 2019 adalah 6.5 triliun rupiah; jumlah terbesar dari seluruh sektor industri pertambangan batu bara dan mineral di Indonesia ${ }^{4}$. Pada tahun yang sama, perusahaan ini juga mendapat peringkat emas dari (NCSR) untuk Laporan Berkelanjutan di ajang Asia Sustainability Reporting Ranking ${ }^{5}$ dan meraih delapan penghargaan dari Indonesian Mining Assosiation, salah satunya pada kategori Perusahaan Pelaksana Pemberdayaan Masyarakat Terbaik $^{6}$.

KPC menyatakan bahwa pelaksanaan Tanggung Jawab Perusahaan atau Corporate Social Responsibility (CSR) dan program pemberdayaan masyarakat yang diselenggarakannya selaras dengan tujuan-tujuan pembangunan berkelanjutan (SDGs). Guna mencapai tujuan $S D G s$, pelaksanaan CSR dan pemberdayaan masyarakat di KPC dilakukan melalui pelibatan aktor-aktor lokal di masyarakat sebagai agen perubahan (Laporan Berkelanjutan: Membangun untuk Negeri, 2019). Mereka ini adalah para wirausahawan sosial.
KPC memiliki tujuh bidang program pemberdayaan masyarakat yang mencakup bidang agribisnis, usaha mikro-kecil, kesehatan, pendidikan, infrastruktur, peningkatan kapasitas, dan konservasi alam dan budaya. Artikel ini membahas proses kemunculan kewirausahaan sosial dalam konteks pemberdayaan masyarakat dan CSR KPC terutama menelusuri proses kemunculan dan peran mereka dalam kegiatan pemberdayaan masyarakat/CSR perusahaan tambang dengan menampilkan kisah tiga orang wirausahawan sosial dan serta peran mereka dalam kegiatan pemberdayaan dan CSR dari PT.KPC.

\section{Kajian Pustaka}

Corporate Social Responsibility (CSR) adalah terminologi bisnis yang berkembang pada dekade 1950-an. Semenjak itu, CSR menjadi bahan kajian ahli ekonomi dan manajemen sekaligus panduan praktis bagi para pebisnis. Tidak ada definisi baku mengenai CSR sehingga realisasinya pun memiliki spektrum yang luas. Pada konteks tata kelola organisasi, International Standard Organization menerbitkan ISO 26000 pada 2010 yang berisi Guides on Social Resonsibility. Panduan mengenai tanggung jawab sosial ini adalah hasil pengembangan dari pengarusutamaan wacana lingkungan dan pembangunan berkelanjutan hasil Rio Earth Summit on Environment 1992 dan World Summit on Sustainable Development di Johannesburg 2002.

Pada awalnya, standar ini masih menggunakan istilah corporate social responsibility, tetapi pada dalam proses penyusunannya, istilah 'corporate’ dihilang-kan untuk meluaskan fungsi

4 Rahman, "Sangatta, Kota Tempat Tambang Batu Bara Terbuka Terbesar di Dunia”, https://ekonomi.bisnis.com/ $\mathrm{read} / 20170629 / 44 / 666775 /$ sangatta-kota-tempat-tambang-batu-bara-terbuka-terbesar-di-dunia.

5 Dwijayanto, “BUMI dan KPC meraih kategori emas dari Asia Sustainability Reporting”, https://industri.kontan.co.id/news/bumi-dan-kpc-meraih-kategori-emas-dari-asia-sustainability-reporting

6 Bayu, "Asosiasi Tambang Beri Penghargaan ke Jokowi dan 23 Perusahaan Artikel ini telah tayang di Katadata. co.id dengan judul “Asosiasi Tambang Beri Penghargaan ke Jokowi dan 23 Perusahaan”, https://katadata.co.id/ berita/2019/11/20/asosiasi-tambang-beri-penghargaan-ke-jokowi-dan-23-perusahaan 
panduan ini bagi semua jenis organisasi, tidak hanya perusahaan saja. Perbedaan utama pada standar ini dengan standar internasional lainnya yaitu ISO 26000 (2010) lebih bersifat sebagai panduan bagi organisasi dalam melakukan kegiatan yang bertanggungjawab, dan bukan kumpulan persyaratan seperti pada standar-standar lain yang biasanya dikeluarkan oleh ISO. Di dalam ISO 26000 (2010), social responsibility didefinisikan sebagai:

"Responsibility of an organization for the impacts of its decisions and activities on society and the environment, through transparent and ethical behavior that contributes to sustainable development, health, and the welfare of society; takes into account the expectations of stakeholder; is in compliance with applicable law and consistent with international norms of behavior; and it integrated throughout the organization and practiced in it relationships."

Pada ISO 26000 (2010) terdapat tujuh subjek inti tanggung jawab sosial yaitu: 1) Pengembangan Masyarakat; 2) Konsumen; 3) Praktik Kegiatan Institusi yang Sehat; 4) Lingkungan; 5) Ketenagakerjaan; 6) Hak asasi manusia; 7) Tata Kelola Organisasi (Organizational Governance).

Sementara itu, kegiatan kewirausahaan dalam banyak literatur dilihat sebagai pendorong penting bagi pertumbuhan ekonomi, terutama di negara-negara berkembang (Choukir dan Hentati, 2013; Simpeh, 2011; Tweneboah-Koduah dan Adusei, 2016). Hal ini karena kegiatan kewirausahaan menciptakan dan menambah nilai dari suatu sumber daya. Ahli ekonomi abad 19 dan 20 seperti Jean Baptise Say dan Joseph Schumpeter menyatakan bahwa karakteristik utama yang tampak dari wirausahawan adalah inovasi dan pembaharu terhadap proses produksi barang atau jasa. Mereka mampu melihat peluang-peluang baru yang belum tergarap. Wirausahawan menjadi agen perubahan ekonomi dengan melayani/membangun pasar baru, atau menciptakan cara-cara baru dalam melakukan sesuatu. Mereka mendorong ekonomi maju ke depan. Peter Drucker menggarisbawahi "the entrepreneur always searches for changes, responds to it, and exploits it as an opportunity" (Dees, 1998).

Di dalam artikel ini, definisi operasional 'kewirausahaan sosial' merujuk pada suatu etos, semangat dan atau pendekatan yang bertujuan untuk menyelesaikan isu sosial dengan prinsip mengedepankan inovasi, kolaborasi, pengembangan jaringan, kemampuan kreatifitas melihat peluang baru, serta praktik pemberian nilai tambah dengan mengeksploitasi sumber daya yang tersedia (ekonomi, sosial, budaya, dan politik) melalui adopsi prinsip-prinsip kewira-usahaan. Pembeda utama antara 'kewirausahaan' dengan 'kewirausahaan sosial' adalah kegiatan kewirausahaan sosial tidak selalu berorientasi pada keuntungan finansial. Kewirausahaan sosial dapat mewujud dalam beragam bentuk yang bisa ditemukan pada individu, organisasi maupun jaringan. Bagi wirausahawan sosial, misi sosial lebih nyata dan berada di tengah cakrawala kegiatan mereka. Wirausahawan sosial sering kali menjadi ujung tombak dalam penyelesaian masalah sosial.

Smith dan Steven (dalam Malunga, Iwu, dan Mugobo, 2014), mengemukakan tiga macam kategori kewirausahaan sosial yaitu: 1) Social bricoleurs: mereka yang mengalami langsung masalah sosial di komunitinya dan menargetkan aksi pada pemecahan isu sosial lokal; 2) Social constructionist: mereka yang mampu menemukenali peluang yang tak disadari oleh orang lain. Cakupan social constructionist lebih luas dari sekedar masalah lokal, dan kegiatan usahanya dapat direplikasi di tempat lain; dan 3) Social engineers: mereka yang fokus pada isu skala luas yang terkait dengan perhatian banyak pihak 
(contohnya isu pengangguran) dan menemukan solusi untuk mengubah keseluruhan sistem agar lebih tanggap dengan masalah sosial.

Bentuk-bentuk masalah sosial di antaranya adalah pengangguran, kemiskinan, kejahatan, penyakit kejiwaan dan kekerasan rumah tangga. Masalah sosial seringkali terjadi secara struktural, melekat pada kondisi dan sistem sosial masyarakat sehingga penyelesaiannya pun harus berpusat pada usaha-usaha mengubah kondisi dan struktur sosial masyarakat. Pemberdayaan masyarakat bisa menjadi jalan keluar dari masalah sosial dengan mengajukan cara atau pendekatan alternatif terhadap struktur sosial, politik dan ekonomi yang berjarak dengan solusi masalah (Ife, 1995). Pada kondisi ini, peran kewira-usahaan sosial sangat penting karena mereka mengisi celah yang disebabkan oleh kemandekan struktur, ketidakefektifan tata kelola, pemborosan dan ketidaksinambungan antara institusi besar (negara, korporasi, atau LSM) dan masyarakat.

Selain peran dalam finansial, wirausahawan sosial juga berperan dalam pengakumulasian modal sosial yang dapat mendorong gerakan perubahan sosial sebagai jalan pemecahan masalah sosial di masyarakat. Pada banyak kasus, wirausahawan sosial menciptakan jalan keluar berkelanjutan bagi permasalahan sosial (Crisan dan Borza, 2012). Contohnya adalah Grameen Bank di Bangladesh, Rumah Sakit Mata Aravind di India dan Sekem di Mesir. Ketiganya menjembatani sumber daya yang sering kali tidak dimiliki masyarakat untuk mengatasi masalah sosial secaar kreatif, dan pada gilirannya dapat mengubah struktur sosial masyarakat (Malunga et al., 2014).

\section{Metode}

Studi ini menggunakan pendekatan kualitatif.
Data primer dikumpulkan melalui wawancara mendalam dan pengamatan terlibat. Data sekunder dikumpulkan dari laporan internal perusahaan dan materi-materi presentasi internal perusahaan. Data utama studi ini berupa kisah mengenai tiga wirausahawan sosial yang melakukan kegiatannya dalam kerjasama dengan program-program pemberdayaan masyarakat oleh PT. KPC. Program itu antara lain Pengembangan Agribinis melalui Peternakan Unggas, Pengembangan UMKM, Pelestarian Alam dan Budaya, serta Peningkatan Kapasitas Kelembagaan Pemerintahan Desa dan Masyarakat.

Data penelitian dianalisis dengan menggunakan metode analisis etnografi post-modern. Cerita pendek yang diperlakukan sebagai wacana yang bukan hanya bertujuan menggambarkan proses dan interaksi sosial, tetapi juga menggali ingatan, harapan, pengalaman pribadi, preferensi personal, keputusan-keputusan subjektif para pelaku. Pada studi ini, cerita pendek menggambarkan proses pembentukan jiwa kewirausahaan sosial dan pegarahannya pada tujuan-tujuan ekonomi dan sosial (Clair, 2003). ${ }^{7}$ Tujuannya agar fenomena kewirausahaan sosial dipahami sebagai proses budaya sebagai bahan tafsir dan analisa.

\section{Hasil dan Pembahasan}

Kisah tiga wirausahawan sosial di wilayah pertambangan ini adalah mengenai Andrie Yuniarsa, penggerak peternak ayam kampung di Kecamatan Bengalon; Aulya Vinanda Husaini, pengusaha dan aktivis komunitas pengusaha muda lokal di Sangatta; dan Andika Yohantoro, pegiat usaha pengelolaan sampah di Sangatta. Ketiga orang ini bekerjasama dengan program kegiatan pemberdayaan masyarakat PT. KPC

\footnotetext{
${ }^{7}$ Kutipan asli berasal dari Stephan A Tyler (1986) " a postmodern ethnography is a cooperatively evolved text consisting of fragments of discourse intended to evoke in the minds of both reader and writer an emergent fantasy of a possible world of common sense reality, and thus provoke and aesthetic integration that will have a therapeutic effect."
} 
dan kiprah mereka menggambarkan peran mereka sebagai wirausaha sosial yang menjadi agen sosial penting dalam upaya pemberdayaan masyarakat dan peningkatan partisipasi masyarakat dalam pembangunan di wilayahnya masing-masing.

\section{Perjuangan Peternak Ayam}

Andrie Yuniarsa adalah wirausahawan sosial di Kecamatan Bengalon. Pengalamannya menjadi peternak ayam kampung membuatnya berkeinginan kuat menjadikan peternak Indonesia berjaya di kampung halamannya sendiri. Hal inilah yang motivasinya menjadi aktivis dan wirausahawan sosial melalui HIMPULI (Himpunan Peternak Unggas Lokal Indonesia). Saat ini, ia aktif di HIMPULI Provinsi Kalimantan Timur menjabat sebagai Sekretaris Umum dan juga sebagai pendamping kegiatan peternak ayam lokal mulai dari tingkat kecamatan, hingga tingkat provinsi. Andrie bukan warga asli Bengalon. Ia pindah ke sana setelah bekerja di perusahaan tambang, dan menetap setelah menikah dengan istrinya yang warga setempat.

Sebetulnya Andrie berlatar belakang pendidikan sarjana geodesi. Pada kurun waktu 2005-2014, ia pernah bekerja sebagai teknisi ukur lahan dan pengurusan perizinan dan pembebasan lahan di beberapa perusahaan tambang. Namun, rasa pesimisnya pada usaha pertambangan membuatnya memutuskan berhenti bekerja pada 2014 dan beralih profesi sebagai peternak ayam kampung.

Ketertarikan Andrie pada usaha peternakan ayam, diawali dari keikutsertaannya dalam bisnis penggemukan ayam kampung yang sedang dirintis oleh ayah mertuanya. Semula, ayah mertua Andrie beternak ayam petelur tetapi usahanya berhenti karena masalah keuangan. Setelah mengikuti serangkaian pelatihan dan studi banding peternakan ayam kampung yang diselenggarakan oleh KPC di Keca- matan Bengalon, ia dan mertuanya pun tertarik beternak ayam kampung. Ia memiliki modal kandang bekas ayam petelur milik mertua, sedangkan stimulan bibit disediakan oleh KPC. Andrie pun bergabung dengan mertuanya merintis peternakan ayam kampung dengan dukungan teknis dari CSR KPC bekerjasama dengan Dinas Pertanian Kutai Timur. Program ini membuat budidaya ayam kampung marak di Kecamatan Bengalon; dan mendorong terbentuknya banyak kelompok peternak. Andrie tergabung dalam kelompok peternak bernama Kelompok Tani Perdau Mandiri. Pada 2015, Dinas Peternakan Provinsi Kalimantan Timur menyelenggarakan lomba kelompok peternak berprestasi. Sebagai syarat mengikuti lomba, Andrie dan Perdau Mandiri bergabung dengan kelompok peternak lain yang bernama Kelompok Tani Menuai Bakti. Mengusung nama kelompok Menuai Bakti, Andrie dan rekan-rekannya berhasil mendapat juara pertama, baik di tingkat provinsi maupun tingkat nasional. Kelompok mereka juara karena dianggap sebagai karya inovatif, beternak ayam di lokasi yang sulit dari pasokan bahan budidaya (pakan, bibit) dan pasar. Berada di lokasi yang jauh dari pusat ekonomi kota, membuat Andrie dan rekannya terdorong melakukan aneka terobosan budidaya. Sumber daya pakan lokal dimaksimalkan untuk menekan biaya produksi. Para peternak berjejaring dan berbagi informasi dan akses pada bahan pakan lokal. Mereka bekerjasama dengan para petani jagung di Bengalon. Petani jagung menjual hasil pada peternak, dan peternak menjual pupuk kandang pada petani. Selain itu, peternak juga bekerjasama dengan perusahaan kelapa sawit. Mereka membeli limbah pabrik sawit sebagai bahan pakan ayam kampung yang murah tetapi berkadar protein tinggi.

Pada 2015, total populasi ternak ayam kampung dari 14 kelompok peternak dapat mencapai 20.000 ekor ayam. Jumlah ini sangat berlimpah dan semuanya masuk ke pasar tra- 
disional dan atau rumah makan-rumah makan di Sangatta. Ruang gerak pemasaran pun semakin sempit, dan beresiko memercik api konflik di antara para peternak. Merespon situasi ini, Andrie membuat inovasi untuk mengatasi produksi yang berlimpah, yaitu membangun rumah potong unggas (RPU) dan memproduksi ayam beku siap masak dalam kemasan, nugget ayam, dan jeroan beku. Produk dipasarkan ke supermarket lokal. Pengembangan rumah potong kembali didukung oleh KPC dan Pemerintah Provinsi Kaltim hingga RPU-nya mengantongi lisensi halal dan mendapat nomor kontrol veteriner (NKV).

Selain mempelopori budidaya dan produksi ternak, Andrie juga menginisiasi kegiatan kewirausahaan sosial. Ia menyadari betapa posisi petani dan peternak kecil sangat terpinggirkan. Menurutnya, sektor pertanian di Indonesia menghadapi masalah yang rumit. Padahal sektor ini erat dengan pangan yang merupakan sektor strategis. Pangan menentukan kualitas hidup manusia Indonesia. Sayangnya, dunia pertanian di Indonesia, terutama di wilayah tempat tinggalnya, ibarat benang kusut aneka masalah; mulai dari usia petani yang makin tua dan tak ada regenerasi, keterbatasan sediaan bibit, sarana produksi pertanian, tingginya alih fungsi lahan, ketergantungan petani terhadap (CSR) perusahaan tambang, pemenuhan aturan pasca panen, distribusi dan pemasaran produk, penegakan regulasi, akses terhadap pasar dan sederet masalah lainnya.

Di bidang peternakan, peternak ayam kampung harus bersaing memasarkan hasil ternaknya di tengah derasnya persaingan bisnis ternak ayam (ras maupun silangan). Belum lagi masalah keterbatasan bibit ayam lokal asli Indonesia yang berkualitas. Padahal, beternak ayam kampung berarti juga terlibat langsung dalam upaya pelestarian unggas lokal Indone-

sia - melestarikan 'plasma nutfah' Indonesia ${ }^{8}$. Ini berarti mendukung kedaulatan pangan Indonesia, lebih dari sekadar ketahanan pangan. Ia pun tergerak mengorganisir sesama peternak untuk membentuk Koperasi Bengalon Karya Bakti Mandiri pada 2017. Koperasi ini berperan dalam usaha penguatan modal dan kapasitas petani-peternak, sekaligus mengintegrasikan hasil panen untuk memenuhi kebutuhan produksi anggota.

Para petani-peternak juga rutin berkumpul di rumahnya untuk sekedar curhat, menggali terobosan baru, atau rapat pembagian tugas untuk acara panen di desa mereka. Acara panen selama ini dilakukan hanya sekedar seremonial dan bermuatan politis-strategis. Ia dan rekan-rekan petani-peternak akan mengemas ulang kegiatan itu menjadi ajang bagi petani-peternak untuk langsung menyampaikan masalah pada Bupati dan pejabat yang hadir. Tujuannya agar para aparat pemerintah mengetahui dan memahami masalah riil di lapangan.

Selain itu, di tingkat provinsi, Andrie juga membangun jaringan komunikasi peternak unggas lintas kabupaten-kota yang dikukuhkan dan diwadahi dalam HIMPULI Kaltim pada tahun 2017. Pada tahun yang sama, berkat kegiatan advokasi yang ia lakukan, KPC, Kementerian Pertanian RI, Pemerintah Kabupaten Kutai Timur dan HIMPULI menandatangani Memorandum of Understanding tentang kesepahaman rencana pengembangan usaha ternak unggas lokal di Kabupaten Kutai Timur, salah satunya dengan pengembangan dan pembangunan pusat pembibitan ayam lokal di Kabupaten Kutai Timur; satu-satunya di Kalimantan Timur. Andrie berharap, upaya ini akan menjadikan peternak Indonesia berjaya di kampung halamannya sendiri.

\section{Komunitas Pengusaha Lokal dan Solusi}

\footnotetext{
${ }^{8}$ Indonesia adalah salah satu dari tiga wilayah yang dinyatakan sebagai pusat domestikasi ayam di dunia. Pusat domestikasi ayam lainnya adalah Lembah Hindus, India dan Sungai Kuning, Cina. Ayam domestikasi Indonesia berasal dari satu nenek moyang, yaitu ayam hutan merah (red junglefowl, Gallus gallus.
} 


\section{Pengangguran}

Aulya Vinanda Husaini adalah aktivis di Komunitas Tangan Di Atas (TDA) sejak 2017. Komunitas ini beranggotakan para pengusaha UMKM nasional, kebanyakan anak muda, dan berhasil pada bidang usahanya. Tujuan mereka mengorganisir diri adalah saling membantu sesama pengusaha Indonesia dengan konsep keswadayaan dan gotong-royong. Nilai utama dalam TDA adalah silaturahmi dan saling berbagi dan membantu dalam hal ilmu berdagang, teknik pembukuan, pengalaman dalam pemenuhan syarat aturan, informasi pemasok, solusi pemasaran, bahkan berbagi pangsa pasar. Forum saling berbagi ini diselenggarakan dalam format sesi kopi darat, sesi lokakarya, sesi kelompok mentoring, kuliah WhatsApp, sampai acara Pesta Kewirausahaan.

Prinsip anggota TDA 'yang besar membantu yang kecil'. Pengusaha yang beromset 100 juta per bulan, membantu dengan menjadi mentor pengusaha yang beromzet 50 juta, sedangkan pengusaha yang beromzet 200 juta menjadi mentor pengusaha yang beromset 100 juta dan begitu seterusnya. Bisnis, bagi mereka tidak melulu mengenai kompetisi dan profit, tapi bisa juga mengenai saling bantu dan kolaborasi. Jumlah anggota TDA seluruh Indonesia sekitar 12 ribu orang. Sebanyak 179 orang anggota ada di Kutai Timur. Jumlah ini terhitung kecil dibandingkan dengan jumlah penduduk Kutai Timur yang bekerja di bidang pertambangan maupun perkebunan. Namun, gerakan kecil ini diyakini Aulya Vinanda Husaini dapat memutus ketergantungan orang terhadap ekonomi tambang.

“Apabila usaha anggota TDA semakin besar maka akan ada semakin banyak lapangan pekerjaan, sekaligus membuka peluang usaha lain bagi warga lokal yang tidak terserap pada usaha pertambangan... Makanya, kalau pengangguran di Sangatta ini banyak, ya solusinya ada di situ, gak ada lain, ya minimal dari kita-kita yang kecil-kecil ini..." (Aulya Vinanda, Aktivis Komunitas TDA)

Kiprah Aulya di Komunitas TDA tak lepas dari pengalamannya sebagai pengusaha dan pengurus BUMDES. Aulya memiliki latar belakang pendidikan pascasarjana Ilmu Kelautan di Malaysia pada 2006. Ia pernah bekerja di perusahaan kargo milik orang Indonesia. Karirnya dimulai dari mulai dari urusan pergudangan, pemasaran, hingga customer service. Pada 2012, ia pindah ke Kota Balikpapan, Kalimantan Timur setelah setahun sebelumnya ia menikah dengan orang asal Sangatta. Di Kota Balikpapan, ia mengalami kesulitan mendapatkan pekerjaan di perusahaan meski memiliki latar belakang pendidikan tinggi dan pengalaman kerja. Ia dan istrinya memutuskan membuka aneka usaha. Sampai akhirnya mereka memutuskan membuka usaha kedai pizza di Kota Balikpapan. Di tahun 2014, Ia membuka usaha kedai pizza di Sangatta dan dalam dua tahun usahanya maju pesat sampai ia dapat memiliki tiga outlet.

Selain berbisnis pribadi, Aulya pernah pernah menjadi direktur Badan Usaha Milik Desa (BUMDESA) Swarga Bara di Sangatta pada kurun waktu 2016-2017. Tugas pertama dan utama yang ia lakukan adalah pembenahan empat unit usaha BUMDES, yaitu: unit usaha air bersih, unit simpan pinjam, unit perkebunan kelapa sawit dan unit ekowisata. Masalah di tiap unit hampir sama yaitu pengelolaan keuangan, laporan yang tidak transparan, isu komunikasi antara BUMDESA dengan nasabah simpan pinjam, sampai masalah 'nonteknis' yang menghambat produktivitas unit usaha.

Aulya merevitalisasi BUMDES dilakukan secara bertahap: mulai dari mengubah persepsi warga desa mengenai unit usaha simpan pinjam, mengubah model dan aturan main simpan-pinjam, efisiensi operasional di unit usa- 
ha air bersih, transparansi pelaporan arus kas, membangun hubungan dengan kelompok tani yang terlibat dalam unit usaha kelapa sawit, pengembangan usaha baru, hingga mengembangkan sistem penggajian berdasarkan keuntungan per unit usaha. Usaha perbaikannya menunjukkan hasil.

Pada 2016 dilakukan pengukuran tingkat perkembangan BUMDESA di sekitar wilayah dampingan KPC. BUMDESA Swarga Bara mendapat nilai rata-rata tertinggi dengan capaian 75\% mengungguli 24 lainnya dan masuk kategori BUMDESA 'Berkembang Mandiri'. Pada 2017 BUMDESA Swarga Bara dinobatkan sebagai BUMDESA Terbaik dari seluruh BUMDESA dampingan PT.KPC yang berada di wilayah lingkar tambang 9 .

Di Komunitas TDA, Aulya merasa bahwa kesempatan mewujudkan impian itu semakin besar saat kolaborasi dengan PT. KPC. Komunitas TDA telah menandatangani $M o U$ dengan KPC untuk berkolaborasi dalam program pengembangan UMKM Kutai Timur. Komunitas TDA Kutai Timur menjadi pelaksana kegiatan Kutimpreneur dan 'UKM Tangguh'. Dua program tersebut bertujuan melahirkan pengusaha lokal Kutai Timur yang dapat membuka peluang kerja baru tanpa bergantung pada usaha pertambangan. Kutimpreneur menargetkan enam puluh lulusan yang akan menjadi wirausahawan, sehingga sampai pada tahun ketiga usaha lulusan Kutimpreneur dapat menyerap 240 tenaga kerja berupah standar $\mathrm{UMR}^{10}$. Begitu juga UKM tangguh: meningkatnya kapasitas UKM lokal, turut memperbesar putaran ekonomi UKM lokal Kutai Timur. Upaya membangun ekonomi non-tambang sedikit-sedikit dapat terwujud.

\section{Bank Sampah Menata Kota}

\footnotetext{
${ }^{9}$ Resume dan Analisis BUMDESA di 3 Kecamatan Tahun 2016 (tidak diterbitkan). 10 Rencana program Kutimpreneur (PT. Kaltim Prima Coal, 2018). Rujukan: bahan presentasi section LBD, Dept Community Empowerment, Divisi ESD. Tidak diterbitkan.
}

Sampah adalah masalah lingkungan yang penting di Sangatta. Andika Yohantoro tergerak untuk mengajak warga muda di Sangatta mengatasi persampahan dengan mendirikan kelompok Remaja Kreatif Peduli Lingkungan (RKPL) pada 2009. Kelompok ini menginisiasi jasa pengumpulan, pemilahan sampah, dan bank sampah. Manfaat kegiatan kelompok itu telah mendapat pengakuan dari Bupati Kutai Timur. Andika pernah dimintai sarannya untuk pengelolaan sampah berbasis masyarakat di Kabupaten Kutai Timur. Atas sarannya, Pemkab Kutim memberikan 86 unit motor gerobak tiga roda untuk mengumpulkan sampah di wilayah di Kota Sangatta. Satu unit motor digunakan untuk melayani 3-4 wilayah RT. Melalui bantuan ini, kegiatan pengelolaan sampah berbasis satuan RT pun dimulai di Sangatta. Andika juga berkolaborasi dengan KPC pada saat yang bersamaan melaksanakan program Gerakan Bersih, Sehat, dan Mandiri (GERAK BERSEMI) di wilayah Kecamatan Sangatta Utara dan Kecamatan Sangatta Selatan.

Motivasi Andika melakukan pengelolaan sampah di Sangatta bermula sejak 2005. Saat itu, ia melihat banyaknya sampah di jalanan kota akibat kebiasaan warga membuang sampah di tengah jalan. Saat itu belum ada keterlibatan pemerintah daerah dalam pengelolaan sampah. Merasa jengah pada sampah, ia bersama teman-temannya di Ikatan Remaja Masjid (IRMA) Gang Rejeki Desa Teluk Lingga, Kecamatan Sangatta Utara, Kabupaten Kutai Timur, berinisiatif untuk melakukan perubahan. Idenya sederhana. Mereka berkampanye dampak sampah pada lingkungan, sekaligus menawarkan layanan jasa angkut sampah bagi warga di sekitar Gang Rejeki. Tiap rumah membayar iuran sebesar Rp.5.000,- per bulan, untuk jasa angkut dan pembuangan sampah setiap hari. Kampanye lingkungan ini mere- 
ka sampaikan dari rumah ke rumah. Dukungan datang dari tingkat RT sampai pemerintah desa setempat. Hasilnya, 28 rumah menjadi pelanggan pertama mereka. Walaupun ada pro dan kontra atas inisiatif ini, selang beberapa bulan kemudian, pelanggan mereka bertambah menjadi kurang lebih 200 rumah.

IRMA beranggotakan pemuda-pemudi sekitar Gang Rejeki, berjumlah 25 orang. Sebanyak enam belas orang laki-laki bertugas bergantian untuk mengambil, mengumpulkan, dan membuang sampah ke Tempat Pembuangan Akhir; dan sembilan perempuan bertugas di bagian administrasi, pencatatan, dan penagihan.

Andika berinisiatif meminjam gerobak milik pemulung untuk pengangkutan sampah. Awalnya, mereka tidak melakukan pemilahan sampah. Tujuannya hanyalah agar warga tidak lagi membuang sampah sembarangan. Kebutuhan terhadap lingkungan yang bersih dan sehat ternyata dirasakan oleh semua orang. Pada 2008 pelanggan IRMA mencapai 720 pelanggan, tersebar di 10 RT. Setahun kemudian, jumlah pelanggan meningkat pesat menjadi 1.157, tersebar di 33 RT. Wilayah RT ini berada di sepanjang Jalan Yos Sudarso sepanjang tiga kilometer yang mencakup wilayah Desa Singa Gembara dan Kelurahan Teluk Lingga. Cakupan layanan IRMA pun menjangkau sampai ke pemukiman-pemukiman terdalam. Sejalan dengan peningkatan jumlah pelanggan, IRMA menggunakan satu buah armada motor gerobak roda tiga, bantuan dari Dinas Pekerjaan Umum Kutai Timur. Iuran per pelanggan pun naik menjadi sepuluh ribu rupiah per bulan. Pada awal kegiatan, sampah yang mereka kelola sekitar 1.5 kuintal per hari (sekitar 0.5-0.75 meter kubik), pada 2009 meningkat menjadi rata-rata 1.5 kubik per hari. Mengelola volume sampah yang begitu besar, Andika dan rekan-rekannya di IRMA akhirnya mengenal metode pemilahan sampah.
Sampah yang terkumpul dalam satu hari dipilah berdasarkan jenis sampahnya: non-organik (kaca, plastik, kertas, koran, kardus) dan organik (sisa makanan, daun kering, dsb). Pemilahan sampah ternyata meningkatkan nilai ekonomi sampah. Baik sampah organik maupun sampah non-organik, sama-sama memiliki pangsa pasar. Pemulung sampah di Sangatta datang ke IRMA untuk meminta sampah non-organik, sedangkan sampah organik yang ditampung menjadi bahan baku kompos.

Di saat kegiatan sedang pesat di 2009, ketua masjid melarang IRMA melakukan kegiatan pengambilan sampah. Saat itulah Andika dan rekan-rekan anggota IRMA di gang rejeki mendirikan perkumpulan bernama Remaja Kreatif Peduli Lingkungan (RKPL) yang beranggotakan dari anggota IRMA Gang Rejeki. Mulai saat itu, RKPL identik dengan usaha pengelolaan sampah Kota Sangatta. Pada tahun yang sama, KPC menggelar lomba Kampung Bersemi (Bersih Sehat Mandiri) sebuah kompetisi kebersihan antarkampung/RT di Sangatta Utara dan Sangatta Selatan. Tujuannya untuk meningkatkan kesadaran warga akan kebersihan kampung, dan mendorong tingkat keswadayaan warga untuk menjaga lingkungan yang sehat. Lomba ini adalah bagian dari program Gerakan Bersih Sehat dan Mandiri (Gerak Bersemi) yang digalakkan oleh KPC.

RKPL mendaftarkan 12 RT untuk ikut serta dalam lomba Kampung Bersemi 2009. Salah satu kampung (Gang Prima-Gang Campur Sari) masuk dalam peringkat 10 besar dan mendapat hadiah motor gerobak tiga roda. Serah terima hadiah dilangsungkan di rumah jabatan Wakil Bupati Kutai Timur dan diserahkan langsung oleh Wakil Bupati Kutai Timur. Nama Andika Yohantoro dan RKPL langsung naik daun. Seminggu setelahnya, Andika Yohantoro dapat panggilan telepon dari salah satu staff KPC yang mengundangnya berdiskusi lebih lanjut mengenai kegiatan RKPL serta peluang kerjasama untuk mendukung 
program lingkungan di Sangatta. Diskusi itu menghasilkan kesepakatan mengenai integrasi kegiatan RKPL dengan unit Composting Training Center (CTC) yang didirikan KPC. Sampah organik yang sudah dipilah RKPL dipasok ke CTC sebagai bahan baku kompos. Kerjasama ini adalah awal mula dari pola pengelolaan sampah terintegrasi di Kutai Timur. Pada 2010, Andika Yohantoro bekerja menjadi supir bus karyawan. Terminal bus karyawan kebetulan berada dekat dengan lokasi CTC, sehingga setelah ia selesai bekerja, ia bisa langsung lari ke CTC untuk mengurusi sampah dan produksi kompos.

Pada 2012 Bupati Kutai Timur memanggil Andika Yohantoro dan Kepala Badan Lingkungan Hidup, dan Kepala UPT KPP Dinas Pekerjaan Umum yang bertanggung jawab atas kebersihan kota/kabupaten. Bersama Andika, mereka urun rembug masalah pengelolaan sampah di wilayah Sangatta (wilayah utara dan selatan $)^{11}$. Andika menyarankan Pemkab Kutai Timur memberikan bantuan motor gerobak ke masing-masing RT di Kota Sangatta untuk mendorong partisipasi dan tanggung jawab tiap komunitas RT terhadap kebersihan lingkungannya. Usulannya pun ditindaklanjuti Pemkab dengan pemberian bantuan 86 unit motor gerobak bagi pengelolaan sampah. Satu unit digunakan untuk melayani 3-4 wilayah RT. Setelah ada bantuan motor gerobak sampah, semakin banyak komunitas warga yang peduli dan semangat dengan masalah sampah dan lingkungan. Namun, di sisi lain RKPL menjadi hampir mati ditinggal pelanggannya yang beralih ke pengelola sampah tingkat RT. Namun demikian, Andika tidak patah harapan. Justru, ia merasa senang karena pada akhirnya warga masyarakat tergerak mengelola sampah.

Andika berpikir untuk melakukan terobosan baru dalam pengelolaan sampah. Bekerjasama dengan CTC yang didirikan KPC ia mendirikan bank sampah. Pengetahuan mengenai pengelolaan bank sampah diperoleh dari studi banding ke Malang. Bank Sampah memberikan pelayanan layaknya bank: nasabah datang untuk menabung, dan mendapat buku tabungan sebagai bukti nilai saldo tabungannya. Nasabah juga dapat mencairkan saldonya di setiap akhir bulan. Bedanya, yang ditabung adalah sampah non-organik. Saldo pun bisa dicairkan dalam bentuk pupuk kompos atau dikonversi nilainya langsung untuk pembayaran layanan pengangkutan sampah. Sampah yang diterima Bank Sampah sudah dipilah oleh RKPL berdasarkan jenis sejak di awal pengambilan. Sampah plastik berdasarkan jenisnya dikemas untuk dikirim ke pengepul yang lebih besar. Nasabah yang menyetorkan sampah plastik akan dihitung nilai uangnya berdasarkan jenis plastiknya dan volume sampah yang disetor. Setiap bulannya, sekali pengiriman sampah non-organik mencapai 3-4 kubik.

Bank Sampah sempat melayani 221 pelanggan yang berasal dari dua desa. Namun, keterbatasan tempat dan sumber daya membuat RKPL kewalahan melayani dan mengelola sampah dari nasabah. Pada akhir 2013, Bank Sampah pun direplikasi di tingkat RT dan Dasawisma. Pihak KPC turut membantu kegiatan bank sampah dengan, meminta kantor-kantor KPC yang dapat diakses oleh kendaraan umum menjadi pelanggan Bank Sampah. RKPL mengambil

11 Program Gerakan Bersih, Sehat dan Mandiri (GERAK BERSEMI) yang diinisiasi KPC dimulai dari tahun 2009 dengan kampanye, sosialisasi dan lomba Kampung BERSEMI akhirnya mendorong Kabupaten Kutai Timur menerbitkan Peraturan Daerah Kabupaten Kutai Timur Nomor 7 tahun 2012 tentang Pengelolaan Sampah. Ada beberapa pasal yang memandatkan pemerintah untuk melibatkan peran serta masyarakat: Pada pasal 6 disebutkan bahwa tugas pemerintah Kabupaten salah satunya adalah menumbuhkembangkan, meningkatkan kesadaran, dan partisipasi masyarakat dalam pengelolaan sampah. Pada pasal 12 butir 2.C disebutkan rencana pengurangan dan penanganan sampah memuat "pola pengembangan kerjasama daerah, kemitraan, dan partisipasi masyarakat; dan pada pasal 30 pemerintah meningkatkan peran serta masyarakat dalam pengelolaan sampah, salah satunya dengan "aktif dalam kegiatan pengurangan, pengumpulan, pemilahan, pengangkutan dan pengolahan sampah... serta pemberian saran, usul, pengaduan, pertimbangan dalam upaya peningkatan pengelolaan sampah.” 
sampah non-organik yang dikumpulkan dikantor-kantor itu. Delapan kantor rutin menyetor sampah non-organiknya. Percepatan replikasi dan kolaborasi antarpihak membuat program Bank Sampah yang digarap RKPL dengan dukungan KPC, mendapat penghargaan Predikat Emas dalam Ajang GKPM (Gelar Karya Pembangunan Masyarakat) Award pada 2013.

Bank Sampah juga mengolah sampah organik menjadi produk kompos yang dijual Rp.2.000 per kg. Kapasitas produksi kompos Bank Sampah mencapai 8 ton per bulan. Andika juga memberikan pendampingan pada usaha lokal. RKPL pun berkembang menjadi pemasok kompos. Setiap bulannya, RKPL memasok 5 ton kompos ke KPC. Atas peluang usaha ini, perkumpulan RPKL pun berubah menjadi CV Rencana Kedepan Pasti Lancar (CV RKPL). Hingga Juli 2018, total pelanggan yang dilayani CV ini sebanyak 528 pelanggan dengan total omzet mencapai Rp.154.080.000. Pada 2017 omzet dari usaha pengangkutan sampah selama setahun mencapai Rp.222.960.000. Selain pengangkutan sampah, bisnis kompos juga membukukan hasil yang positif. Di akhir tahun 2017, CV. RKPL membukukan laba kotor sebesar Rp.113.290.000,- dengan total produksi kompos sebanyak $39.404 \mathrm{Kg}$, serta total volume penjualan kompos mencapai 46.645 $\mathrm{Kg}^{12}$. Harapan Andika Yohantoro selanjutnya adalah agar semua pihak terkait terus bekerjasama menanggulangi masalah sampah di Kutai Timur mengingat kondisi TPS kota Sangatta yang semakin cepat penuh.

Ketiga kisah diatas menggambarkan kemunculan aktor-aktor wirausaha sosial di masyarakat sekitar pertambangan. Andrie Yuniarsa dengan upaya yang ia lakukan sebagai pengusaha sekaligus menempatkannya sebagai seorang wirausahawan sosial kategori social constructionist. Sebab ia mampu menemukenali peluang yang tak disadari oleh orang lain. Aulya Vinanda Husaini dengan rintisan jaringan bisnisnya yang berupaya mengeksplorasi modal sosial menempatkannya dalam posisi sebagai social bricoleurs. Sebab, ia menargetkan pada isu sosial lokal dan ia pun mengalami langsung masalah sosial di komunitinya. Andika Yohantoro dengan kegiatannya masuk dalam kategori wirausaha sosial dalam kategori social constructionist karena ia dapat menemukenali peluang yang tak disadari oleh orang lain.

Setiap aktor wirausaha sosial pada awalnya berupaya keras untuk menciptakan lapangan pekerjaan bagi mereka sendiri dan kemudian mereka membangkitkan kesadaran dan partisipasi masyarakat dalam menangani permasalahan sosial di sekitar tempat tinggal mereka. Pertemuan mereka dengan program-program pemberdayaan masyarakat KPC membuat upaya mereka menggerakkan masyarakat menjadi lebih kuat berkat dukungan teknis melalui pelatihan dan studi banding. Kemampuan mereka mengarahkan sumber daya, inovasi dan membangun jaringan mendapat daya ungkit lebih dengan terbukanya akses terhadap sumber daya CSR.

Prinsip utama dalam kewirausahaan sosial adalah: keuntungan pada kegiatan usaha mereka tidak hanya dihitung berdasarkan keuntungan finansial saja, namun juga memperhitungkan seberapa besar aktivitasnya meningkatkan keberdayaan masyarakat. Dengan itu, kegiatan kewirausahaan mereka menghasilkan nilai dan gerakan sosial yang lebih besar.

Di dalam menjalankan program pemberdayaan masyarakat, perusahaan tambang didukung dengan sumber daya manusia, kekuatan finansial, teknologi, dan kebijakan regulasi. Namun pada kenyataannya, kegiatan pemberdayaan masyarakat tidak sesederhana itu, apalagi pada masyarakat lingkar tambang. Pemberdayaan masyarakat perlu memahami jaringan interak12 Monthly Report Local Business Development PT Kaltim Prima Coal periode Desember 2017 (tidak diterbitkan). 
si masyarakat, organisasi sosial, sistem nilai dan kompleksitas politik lokal. Pemberdayaan masyarakat melalui pendekatan formal dan struktural, beresiko menghasilkan hubungan yang berjenjang, yang malah mengakibatkan ketergantungan bahkan mengukuhkan struktur yang timpang. CSR dapat menghadirkan kesenjangan dan konflik akibat kontradiksi yang ditimbulkannya. Dalam beberapa studi, CSR malah berfungsi sebagai alat pertukaran dan skema pengukuhan kuasa korporasi atas masyarakat lokal -di atas struktur yang sudah timpang (Dolan dan Rajak, 2016; Kirsch, 2016; Sydow, 2019).

Wirausahawan sosial mendorong gerakan sosial dalam pemberdayaan masyarakat ditentukan oleh pengerahan dan pemberian nilai tambah pada modal sosial. Ini pembeda utama kewirausahaan sosial yang tidak dimiliki atau tidak disadari orang lain. Kemampuan berorganisasi dan kecakapan membangun jaringan sosial menjadi faktor penentu keberhasilan kewirausahaan sosial. Mereka dapat menjembatani pihak yang berkepentingan dan mendorong kerja kolaboratif atas dasar kepentingan yang sama. Pada derajat tertentu, mereka mengubah struktur sumber daya, akses teknologi, finansial, serta kewenangan demi mendukung pencapaian tujuan sosial mereka dan perusahaan. Peran ini menjadi kunci bagi keberhasilan program pemberdayaan masyarakat yang dilakukan PT. KPC, bersama para wirausahawan sosial.

Tiga cerita dari Kutai Timur menggambarkan wirausahawan sosial dalam mengisi kesenjangan, dan bukan malah mengeksploitasinya. Mereka jenis yang berbeda dengan makelar, brokerage, yang mengkapitalisasi kesenjangan struktur. Ini adalah fakta yang problematis. Di dalam praktik keseharian, wirausahawan sosial dengan makelar sosial mungkin tidak terlihat jauh berbeda. Mereka sama-sama merepresentasikan kepentingan lokal. Mereka juga memiliki kemampuan berperan dan meng- gerakkan jaringan sosial serta mengkapitalisasi masalah. Namun, wirausahawan sosial dan makelar sosial adalah dua kategori sosial yang berbeda. Pembeda yang paling utama antara keduanya adalah motif. Motif makelar sosial adalah pelestarian kesenjangan struktur (masyarakat lokal - perusahaan - pemerintah) dan mengeksploitasi celah hubungan tersebut untuk motif politik-ekonomi. Makelar sosial seringkali memanfaatkan pembeda 'identitas' (pendatang - pribumi, lokal - non-lokal, dsb) bahkan cara-cara intimidatif (menggerakkan jaringan dan modal budaya) untuk mendorong terjadinya pembagian kewenangan dan keuntungan ekonomis sementara. Dari tiga cerita di atas, alih-alih mengeksploitasi, praktik kewirausahaan sosial berusaha mengubah struktur kesenjangan menuju keseimbangan baru.

Pembangunan berkelanjutan memerlukan wirausahawan sosial; aktor sosial yang berpihak pada penyelesaian masalah lokal dan mampu merepresentasikannya pada level dan jaringan yang berbeda secara berkelanjutan. Para wirausahawan sosial berperan sebagai agen perubahan di masyarakat lokal. Mereka merekatkan, merangkai, dan menggiatkan sumber daya, sekaligus mengantisipasi peluang yang tersedia menuju tujuan dan kepentingan bersama. Skema partisipasi dan kerjasama ini dapat menjawab isu 'kesenjangan institusional' yang disampaikan Gro Brundtland 32 tahun lampau.

Wirausahawan sosial mendorong perubahan dengan menggerakan ekonomi lokal, juga mendorong perubahan sosial melalui inovasi, kreativitas dan kecakapan mengoperasionalkan jaringan serta modal sosial yang dimilikinya. Mereka melihat monumen keberhasilannya dari jauh, sementara yang lain hanya melihat hamparan lahan kosong (Malunga, 2014). Lebih lanjut, tantangan untuk terlibat sungguh-sungguh dalam gerakan pembangunan berkelanjutan (SDGs) ada pada perusahaan tambang. 
Korporasi industri pertambangan mampu memberikan sumber daya, akses dan kepercayaan sehingga kapasitas kewirausahaan sosial lokal bisa bermunculan dalam program pemberdayaan masyarakat. Porsi besar kemitraan seharusnya ditujukan kepada individu, kelompok, maupun jaringan yang memiliki potensi dan kapasitas kewirausahaan sosial yang besar. Komitmen diperlukan di tingkat pucuk perusahaan agar membuka sumber daya (waktu, finansial, akses, dsb.) kepada wirausahawan sosial sebagai investasi berkelanjutan. Idealnya, pendekatan ini menjadi dasar kebijakan tinggi perusahaan tambang dalam kegiatan CSR maupun program pemberdayaan masyarakat untuk mendukung pencapaian pembangunan berkelanjutan.

\section{Simpulan}

Cerita mengenai pemberdayaan masyarakat dan kewirausahaan sosial dapat membantu memahami kompleksitas CSR dan pembangunan berkelanjutan di tingkat lokal. Pemahaman praktik keseharian CSR dari sudut pandang pemberdayaan masyarakat menunjukkan bahwa praktik CSR tidaklah monolitik dan hal ini tampak dalam program pemberdayaan PT. KPC. Perusahaan mengerahkan CSR-nya secara hirarkis melalui kebijakan, bantuan finansial, pendampingan teknis, alokasi anggaran dan tenaga kerja, serta penerapan dan penggunaan teknologi. Pemberian akses dan pelibatan partisipasi aktor kunci, yaitu para wirausahawan sosial menentukan dampak nyata CSR dan inisiatif pemberdayaan masyarakat dalam mencapai seluruh tujuan pembangunan berkelanjutan.

\section{Daftar Pustaka}

Bayu, D. J. (2019). Asosiasi Tambang Beri Penghargaan ke Jokowi dan 23 Perusahaan Artikel ini telah tayang di Katadata.co.id dengan judul "Asosiasi Tambang Beri Penghargaan ke Jokowi dan 23 Perusahaan." Retrieved from https://katadata.co.id/beri- ta/2019/11/20/asosiasi-tambang-beri-penghargaan-ke-jokowi-dan-23-perusahaan

Brundtland, G. (1987). Report of the World Commision on Environement and Development: Our Common Future. Oxford Paperbacks.

Camilleri, M. A. (2017). Corporate sustainability, social responsibility and environmental management: An introduction to theory and practice with case studies. In Corporate Sustainability, Social Responsibility and Environmental Management: An Introduction to Theory and Practice with Case Studies.

Choukir, J., dan Hentati, M. B. (2013). Entrepreneurship Motivation: Tunisian Case. American Journal of Industrial and Business Management.

Clair, R. P. (2003). Expressions of ethnography: Novel approaches to qualitative methods. In Expressions of Ethnography: Novel Approaches to Qualitative Methods.

Crisan, C. (Mitra), Borza, A. (2012). Social Entrepreneurship and Corporate Social Responsibilities. International Business Research.

Dees, J. G. (1998). The Meaning of 'Social Entrepreneurship.

Dolan, C., Rajak, D. (2016). The anthropology of corporate social responsibility. In The Anthropology of Corporate Social Responsibility.

Dwijayanto, A. (2018). BUMI dan KPC meraih kategori emas dari Asia Sustainability Reporting.

Ife, J. W. (1995). Community Development: Creating Community Alternatives-vision, Analysiis and Practice. 59.

International Organization for Standardization 26000. (2010). Discovering ISO 26000. International Organization for Standardization.

Kirsch, S. (2016). Virtuous language in industry and the academy. In The Anthropology of Corporate Social Responsibility.

Laporan Berkelanjutan: Membangun untuk Negeri. (2019). Sangatta, Kalimantan.

Malunga, P., Iwu, C. G., Mugobo, V. V. (2014). Social entrepreneurs and community development. A literature analysis. Mediterranean Journal of Social Sciences.

National Center for Sustainability Reporting. (n.d.-a). Tentang Asia SR Rating. Retrieved from www.ncsr-id.org/id/asia-sr-rating/tentang-asia-sr-rating/.

National Center for Sustainability Reporting. (n.d.-b). Tentang NCSR. Retrieved from 
www.ncsr-id.org/id/about-ncsr/

PT. Kaltim Prima Coal. (2018). Presentasi Kutimpreneur.

Rahman, A. (2017). Sangatta, Kota Tempat Tambang Batu Bara Terbuka Terbesar di Dunia. Retrieved from https://ekonomi.bisnis. $\mathrm{com} / \mathrm{read} / 20170629 / 44 / 666775 /$ sangatta-kota-tempat-tambang-batu-bara-terbuka-terbesar-di-dunia

Simpeh, K. N. (2011). Entrepreneurship theories and Empirical research: A Summary Review of the Literature. European Journal of Business and Management.

Sydow, J. (2019). Global Concepts in Local Contexts: In The Anthropology of Corporate Social Responsibility.

Tweneboah-Koduah, I., Adusei, C. (2016). Entrepreneurship Determinants of Artisans/ Craftsmen in Kumasi Metropolis, Ghana. American Journal of Industrial and Business Management, 06(02), 163-175. 